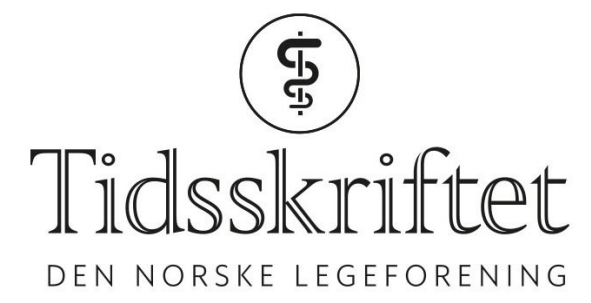

\title{
Geriateren som hater å gå på tomgang
}

INTERVJU

IRENE THORESEN RØNOLD

E-post: irene.thoresen.ronold@tidsskriftet.no Tidsskriftet

Anette Hylen Ranhoff har skrevet flere bøker om hvordan en kan holde seg frisk og rask så lenge som mulig. Selv har hun et ambivalent forhold til det å bli gammel.

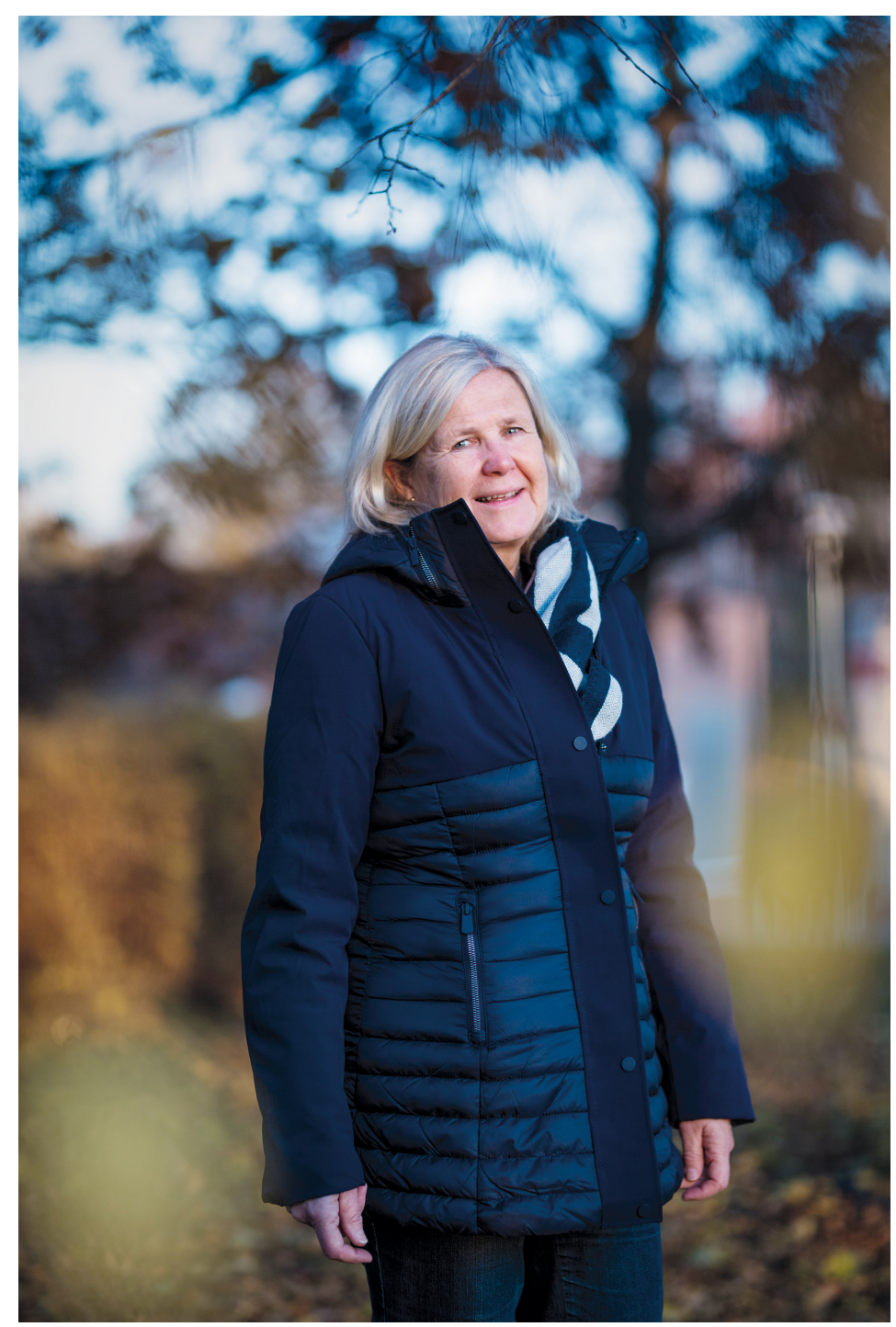

Alle foto: Kristine Lindebø

Det angår oss alle, det her. Det er ikke sikkert du tenker på det i hverdagen, men mye tyder 
på at du kommer til å bli gammel. La oss si at du slipper unna alvorlig sykdom, uhell og ulykker. Da vil du, dersom du likner på gjennomsnittsnordmannen, leve til du er omtrent $82 \frac{1}{2}$ år gammel. Trolig blir du enda eldre.

Som geriater vet Anette Hylen Ranhoff mer enn de fleste om hva som skjer med kropp og hjerne etter hvert som vi blir eldre. Så hva tenker hun selv om det å bli gammel?

- Akkurat det er jo et spørsmål som ...

Det blir stille på legekontoret.

- Jeg tror at jeg, som de fleste, har et ambivalent forhold til det. Jeg pleier å si at alternativet er mye verre. Det skal man holde på, sier hun bestemt.

Så legger hun til:

- Det er jo på mange måter en gave å få lov til å bli gammel.

\section{Nye spørsmål}

- Da jeg begynte med geriatri, tenkte vi at folk over 75 var ordentlig gamle. Nå er de fleste av mine pasienter langt over 8o, forteller Anette Hylen Ranhoff.

\section{Anette Hylen Ranhoff}

Født 1956

Gift, to barn og fire barnebarn

Cand.med., Universitetet i Oslo 1985

Spesialist i indremedisin og i geriatri 1998

Avdelingssjef ved Akuttmottaket, Ullevål universitetssykehus 2000-05

Professor ved Universitetet i Bergen 2009-d.d.

Seksjonsoverlege i geriatri ved Diakonhjemmet Sykehus 2004-d.d.

Forskningsleder for Helsetjenesten til eldre

Har publisert mer enn 120 vitenskapelige artikler

Forfatter av bøkene Godt liv i eldre år og God helse - hva du selv kan gjøre

Medredaktør for læreboken Geratrisk sykepleie

Det er mandag ettermiddag, og Ranhoff befinner seg på kontoret på Diakonhjemmet Sykehus, hvor hun jobber som seksjonsoverlege i geriatri. Her har hun vært siden 2005, da sykehuset, som et av landets første, opprettet en egen avdeling for behandling av hoftebrudd (for øvrig en av hennes store interesser).

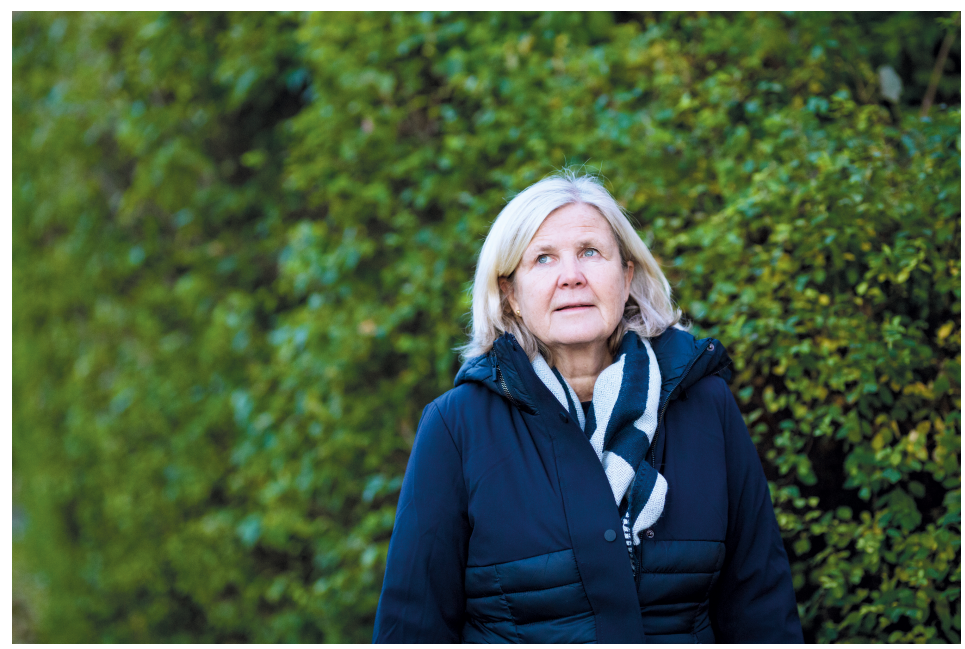

Om noen timer skal hun pakke sakene sine og sykle hjem for å spise middag med ektemannen Frode, som hun ble kjæreste med allerede som tenåring. Men akkurat nå er hun vår, og det er best at vi kommer i gang. Ryktene skal ha det til at hvis man ringer 
Ranhoff, har man akkurat to minutter på seg til å komme til poenget før hun blir utålmodig. Dessuten er hun travel. I tillegg til stillingen som overlege er hun professor ved Universitet i Bergen og seniorforsker tilknyttet Folkehelseinstituttet. For tiden er hun også Norges representant i et EU-prosjekt som skal munne ut i felles retningslinjer om forebygging av funksjonstap hos eldre som er skrøpelige, eller frail, som hun mener er det faglig korrekte begrepet.

Planen var opprinnelig å bli barnelege

- Jeg er i en gruppe som har sett på insidens og prevalens. Vi har sett på hvor mange nye som blir skrøpelige i løpet av et år. Og så har vi sett på hvordan det kan endre seg, sier Ranhoff, og fortsetter:

- Akkurat det er jeg opptatt av. Er det sånn at en person som er skrøpelig på ett tidspunkt, kan bli sterkere og mer robust igjen? Det er det veldig lite forskning på.

\section{Fødetjeneste som nybakt mor}

Hun vokste opp på Frogner, som eldste søster i en søskenflokk på tre. Faren var ingeniør, moren jobbet i bank. Selv bestemte hun seg for å bli lege da hun gikk på gymnaset.

- Men det siste året på gymnaset gjorde jeg vel ikke så veldig stor innsats for å komme inn på medisin. Det måtte jeg ta igjen senere, humrer hun.

Som 22-åring fikk hun plass på medisinstudiet ved Universitetet i Oslo, etter å ha brukt tre år på å ta opp fag og studere på Blindern for å samle poeng. I tillegg tok hun jobb som pleiemedhjelper på Geriatrisk avdeling på Ullevål sykehus.

Resten av karriereløpet har vært preget av effektivitet. Da hun fem år etter studiestart ble mor for første gang, tok det ikke lang tid før hun hadde med seg veslejenta på forelesning. Anette Hylen Ranhoff hadde nettopp vært på utveksling til Australia, og hadde ikke lyst til å være borte fra studiene noe mer.

- Det mest slitsomme var fødetjeneste, mimrer hun.

- Vi måtte være med på et visst antall fødsler for å få godkjent kurs, og jeg gjorde fødetjeneste en måned etter at jeg hadde født selv. Jeg ammet jo, så mannen min måtte komme ned med henne mens vi satt på Ullevål og ventet på fødsler, forteller Ranhoff.

- Det var slitsomt, husker jeg. Men ellers gikk det ganske greit.

\section{Fra ung til gammel}

Planen var opprinnelig å bli barnelege. At hun i stedet valgte å bruke karrieren på gamle mennesker, er det Knut Låke som skal ha skylden for. Den daværende professoren i geriatri i Oslo lurte på om Anette ville delta i et forskningsprosjekt. Det var i 1988. Anette Hylen Ranhoff takket ja, og har ikke angret siden.

- Jeg liker at det er et bredt felt. Geriatri er liksom ikke én enkelt sykdom, det er hele kroppen. Man må forholde seg til pasientens mentale helse, fysiske helse, miljø, omgivelser og nettverk.

- Jeg har alltid tenkt at geriatri høres litt trist ut?

- Det er ikke trist. Noe jeg liker veldig godt, er alle de spennende livshistoriene jeg får ta del

i. Her på poliklinikken driver vi blant annet med utredning av demens og falltendens. Da må vi skape oss et bredt bilde av personen og av livet de har hatt. Da får vi innsikt i en del spennende ting.

Personlig mosjonerer jeg ikke for å bli yngre - jeg mosjonerer for å bli eldre

I løpet av karrieren har Anette Hylen Ranhoff forsket på alt fra demens, delirium og medisinering på sykehjem til ganglag hos eldre og årsaker til hoftebrudd. Hun har skrevet lærebøker i geriatri og flere populærvitenskapelige bøker om hvordan en bevarer god helse 
så lenge som mulig.

- Du liker å jobbe?

- Ja, jeg gjør det.

- De som kjenner deg, sier du er veldig strukturert?

- Hvis du ser på Mac-en min, så er jeg kanskje ikke det. Men at jeg er ganske effektiv, det tror jeg nok. Jeg har en viss evne til å skille det viktige fra det mindre viktige. Og så kjeder jeg meg hvis jeg ikke har noe å gjøre. Jeg hater å gå på tomgang.

- Hva er mindre viktige ting?

- Jeg er ikke veldig huslig av meg. Jeg er ikke interessert i oppussing og interiør. Sånt noe bruker jeg verken tid eller penger på.

- Når var sist dere fornyet noe hjemme? Kjøpte nye gardiner, for eksempel?

- Hehe. Det er nok ikke så ofte vi gjør det. Men mannen min er heldigvis likedan.

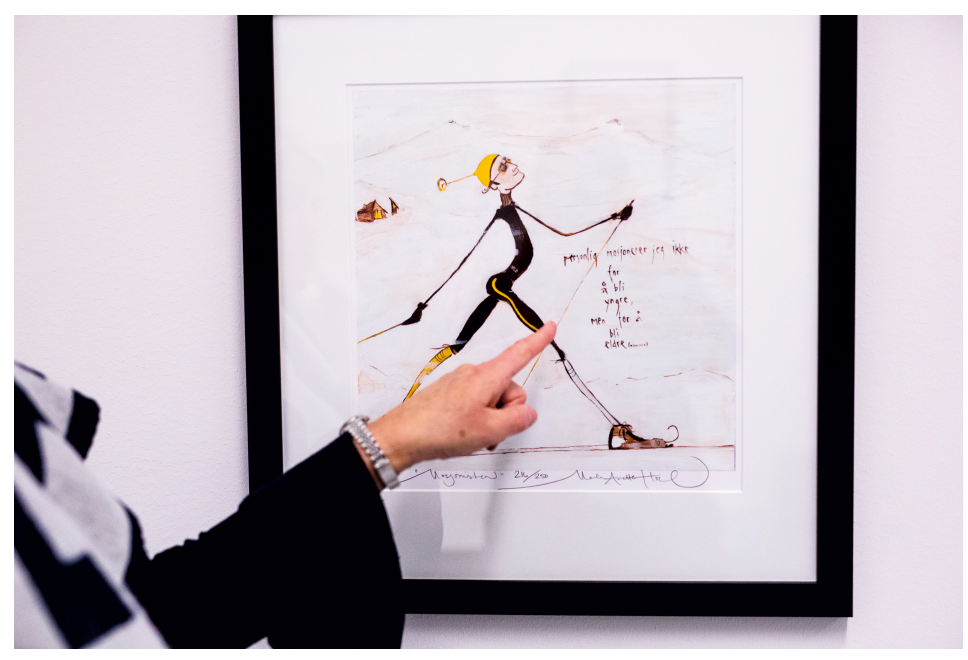

\section{Fant kjærligheten som 15-åring}

Sommeren 1972. Anette er 15 år gammel og på ferie i Stavern med familien. I Sandefjord avholdes det et sommerdiskotek som hun er for ung til å komme inn på, men hun sniker seg til å dra dit likevel. Der møter hun en annen tenåring. Han er fra Røa og på ferie i Sandefjord, heter Frode Ranhoff og har også sneket seg inn.

- Vi har egentlig holdt sammen siden, sier Anette Hylen Ranhoff.

- Hva var det du likte med ham?

- Nei ... Han var stor, sterk og kjekk, humrer Ranhoff, før hun samler seg:

- Vi har veldig mange felles interesser. Det har vi alltid hatt, og vi har alltid brukt mye av fritiden vår sammen. Det har vært bra. Begge er veldig glade i friluftsliv. Det har vært perioder hvor mannen min har syntes jeg har jobbet litt for mye. Men ferie og sånt har vi alltid hatt felles.

Av de to barna er det én som har gått i morens fotspor. Datteren Maren - hun som ble introdusert for medisinstudiet da hun bare var tre måneder gammel - er nå ph.d. og forsker på ambulansemedisin.

- Datteren din fortalte oss at hun var med i ambulansen da hun var ganske liten?

- Ja, det var da jeg var i distriktsturnus på Melhus i Sør-Trøndelag. Hun har fått en sterk relasjon til ambulansetjenesten.

Spis sunt og variert, ikke røyk, ikke drikk for mye alkohol og hold fred med dine nærmeste

- Hva tenker du om at hun har gått samme vei som deg?

- Jeg ble ikke veldig overrasket. Hun hadde absolutt ingen planer om det og begynte på 
statsvitenskap. Da hun hadde gått der i ett år, lurte hun på om jeg kunne skaffe henne sommerjobb. Jeg fikk skaffet henne jobb i resepsjonen på Ullevål. Etter å ha vært der noen uker, kom hun og sa: «Du, mamma, jeg tror jeg har lyst til å studere medisin likevel, jeg».

- Blir det mye prat om fag når dere møtes?

- Ja, det gjør det nok. Men det er mest prat om barnebarna, smiler Ranhoff.

\section{Stuping og langrenn}

På veggen på legekontoret henger en tegning av en langrennsløper. I snirklete løkkeskrift står det: «Personlig mosjonerer jeg ikke for å bli yngre - jeg mosjonerer for å bli eldre».

- Er ikke det fint? Det der kjøpte jeg faktisk på lørdag. Det falt jeg fullstendig for.

Og det viser seg faktisk, kan Ranhoff fortelle, at de som er fysisk aktive også er de som er mest intellektuelt aktive.

Selv har hun alltid vært opptatt av idrett. I dag foretrekker hun langrenn, men som barn drev hun først med svømming, så med stuping. Det siste ble redningen fra det første.

- Jeg gikk på svømmetrening og syntes det ble kjedeligere og kjedeligere. Etter oss på trening kom de som stupte. Jeg så på det, og tenkte: «Fy søren, det ser jo mye morsommere ut». Så begynte jeg på det, men jeg var såpass gammel at det egentlig var litt for seint.

- For seint til hva?

- For seint til å bli veldig god. Jeg var vel 14 år. Men jeg liker fortsatt å stupe. Jeg synes det er veldig gøy.

- Er det sant at du stuper fra timeteren?

- Nei, ti meter stuper jeg ikke lenger fra. Men jeg stuper fra fem-seks.

Hun står bak flere bøker om alder og fysisk aktivitet. På spørsmål om hva en kan gjøre for å holde seg i form så lenge som mulig, oppsummerer hun alt dette i én setning:

- Spis sunt og variert, ikke røyk, ikke drikk for mye alkohol og hold fred med dine nærmeste. Dette med sosiale nettverk er veldig viktig.

Så enkelt. Mosjon er bra, men hardtrening er unødvendig og kan til og med påvirke helsen i negativ retning. Hennes egne studier på deltakere i Birkebeinerrennet viser at for hard trening for eksempel kan føre til atrieflimmer. Faktisk - når man kommer litt opp i årene er det til og med fordelaktig å være bittelitt tykk.

- Det stemmer. Når man er over 65. Så jeg nærmer meg, humrer Ranhoff.

Publisert: 20. februar 2020. Tidsskr Nor Legeforen. DOI: 10.4045/tidsskr.20.0065

(C) Tidsskrift for Den norske legeforening 2020. Lastet ned fra tidsskriftet.no 